\title{
Preliminary Report on Cherokee County, Oklahoma Archeology
}

Lynn E. Howard

Unknown

Follow this and additional works at: https://scholarworks.sfasu.edu/ita

Part of the American Material Culture Commons, Archaeological Anthropology Commons, Environmental Studies Commons, Other American Studies Commons, Other Arts and Humanities Commons, Other History of Art, Architecture, and Archaeology Commons, and the United States History Commons

Tell us how this article helped you.

This Article is brought to you for free and open access by the Center for Regional Heritage Research at SFA ScholarWorks. It has been accepted for inclusion in Index of Texas Archaeology: Open Access Gray Literature from the Lone Star State by an authorized editor of SFA ScholarWorks. For more information, please contact cdsscholarworks@sfasu.edu. 


\section{Preliminary Report on Cherokee County, Oklahoma Archeology}

Creative Commons License

(c) (i) (8)

This work is licensed under a Creative Commons Attribution-NonCommercial 4.0 International License 


\title{
PRELIMINARY REPORT ON CHEROKEE COUNTY, OKLAHOMA ARCHAEOLOGY
}

\author{
Lynn E. Howard
}

Cherokee County is the latest in the state to have its prehistoric conditions investigated by the Department of Anthropology at the University of Oklahoma, in conjunction with the Federal Works Projects Administration. The preliminary survey located several likely sites. Work was begun in July 1939 on a village site and mound located at the junction of Barren Fork Creek and the Illinois River, on a farm owned by M.L. Brackett. It is located in the southwest quarter of Section 18, Township 16 North, Range 23 East. The symbol for this site is Ck. Bk. 1 (Cherokee County, Brackett site $[E d$. note: This is 34CK43]).

There were several problems in the excavation of the site. The main difficulty was the size of the site, as it lay in a narrow strip along the river bank. The width as not over 600 feet, but the length was approximately 1500 feet. This would make the usual grid system too voluminous. A base line was run on the cardinal directions. The central stake was driven at the junction of the east-west line and the south-north line of the grid. From this point, quadrants were laid off. From the central point the quadrant could be expanded indefinitely to the Northeast, Southeast, Southwest, Northwest, and abbreviated in the usual manner. This left the field in very large blocks, which were divided into sections. A section was 250 feet square, and numbered from the central stake of the field in the same manner as sections in a township. The test pits were put in the section sat either 10 or 20 foot intervals, depending on the amount of material found. The test pits were placed as a grid over the section to give the maximum coverage. Each test pit into the clay sub-soil was two feet square. This depth was seldom over two feet. The foreman had a map of the site and plotted each test pit in either red or black ink. Red ink was used when material was found in the test pit, and black when the pit was sterile. In this manner it was possible to see at a glance the portion of the field which had been tested, and the pits which had produced material. Next, the test grid method was incorporated. When an area looked as it if might be productive, a small grid was placed over it. The usual rows and alleys were used with five foot intersections. The test grid was located in the section and ran parallel to it. This would located a specimen in the N.E. Section No. 9, Test No. 1, Stake 3:4 N.3 f, E. 1.5.f. This method was exact although bulky. The features in the test grids were houses, burials and artifacts (Map 1). 


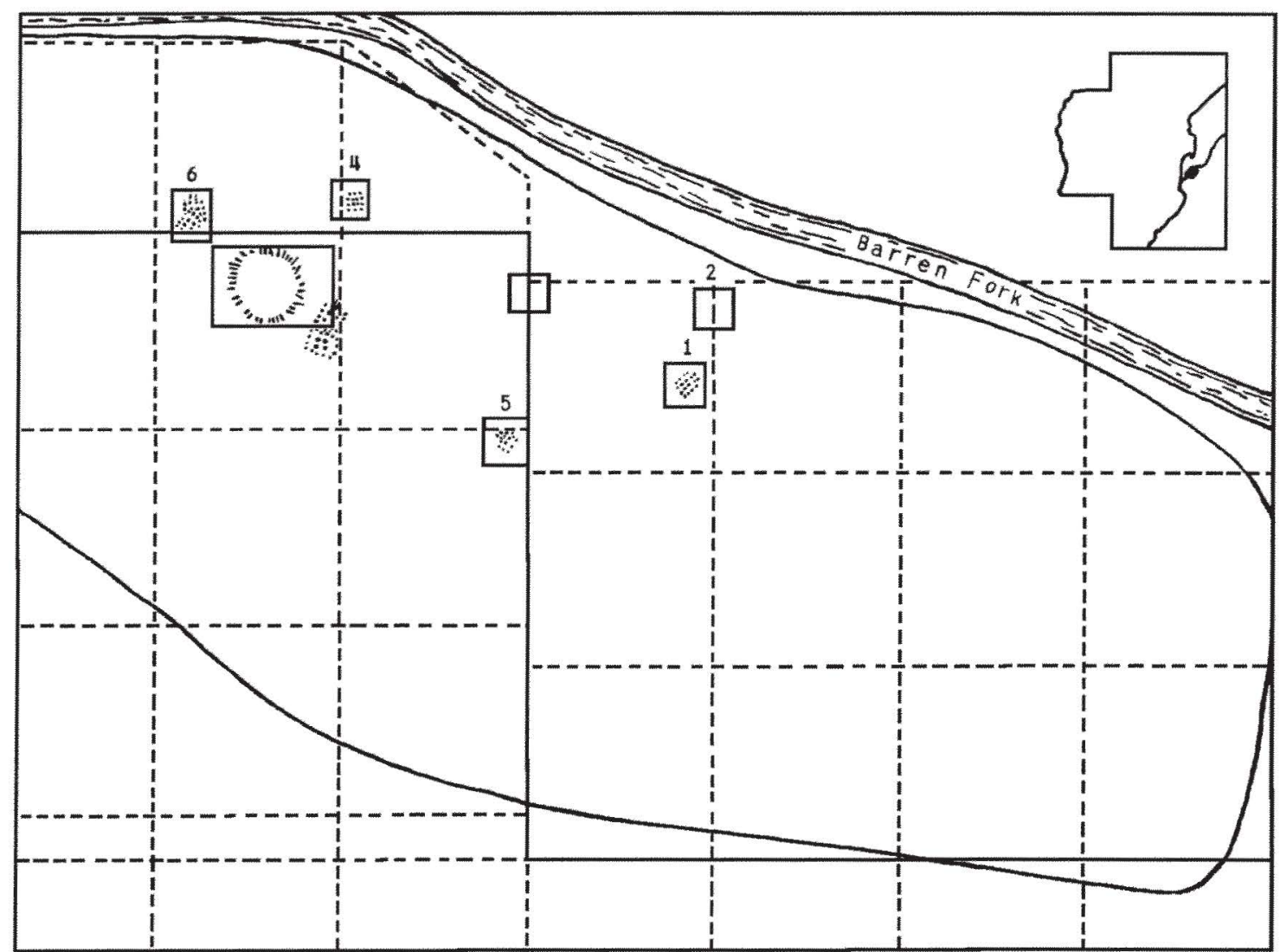

Map 1. Location of test pits at the Brackett site.

\section{VILLAGE SITE:}

The village site is still under excavation and has produced to date seven houses, 15 burial groups, and three artifact groups.

Five of the houses were four center-post, square type with entrance to the East. One was four center-post rectangular. The last was definitely two center-post, rectangular, with an entrance to the East (Maps 2 and 3).

The most common house type was the four center-post square. House No. 1 is a very good example of this type. Except for the clay pedestal, it is similar to the other four center-post, square houses found. $\mathrm{Ck}$. Bk. 1, H-1 was square with four center posts, and a post entrance at the middle of the east wall. The entrance was 6.8 feet long and 3.1 feet wide. The house mixture, or stratum, contained quantities of charcoal, burnt clay and wattle work with deep groove impressions. The stratum was 0.8 foot thick on an average and occurred 0.4 foot below the surface. A small section of baked clay flooring $(2 \times 2$ feet) remained. The posts were marked as discolored shafts of earth containing charcoal, and extending into the yellow clay sub-soil. The walls of the house were rows of 


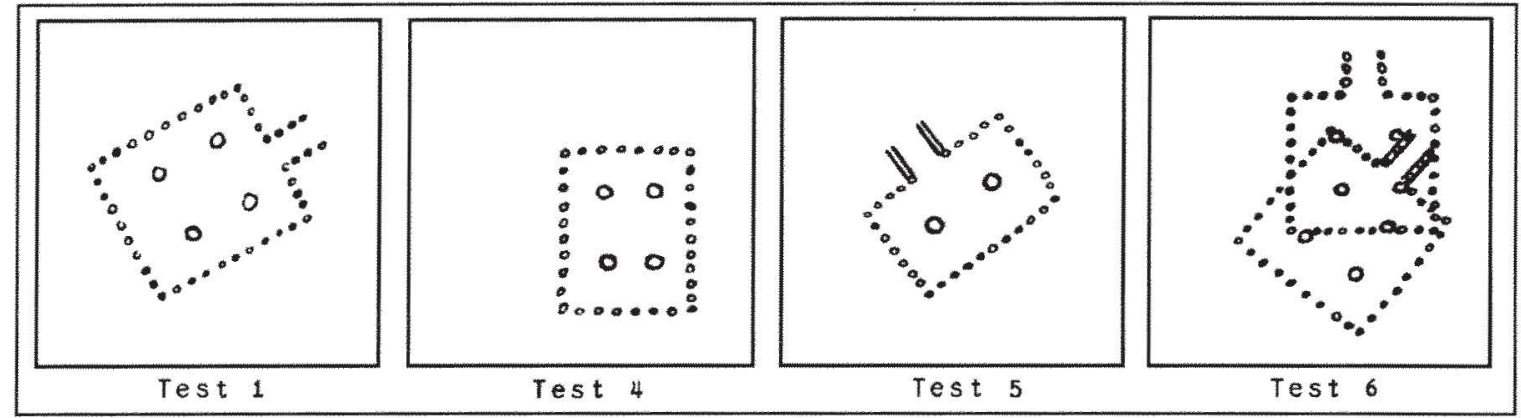

Map 2. Houses excavated at the Brackett site.

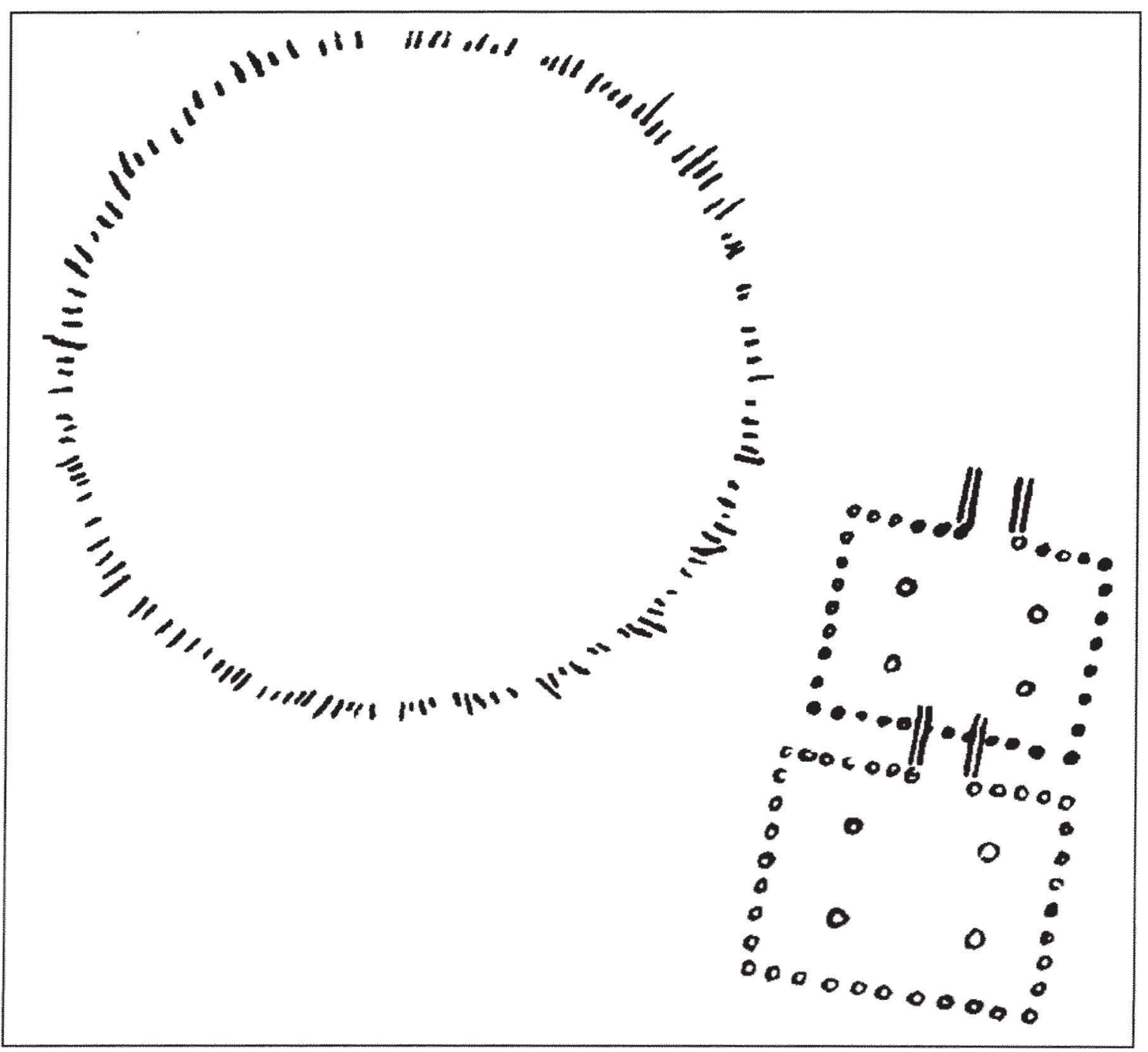

Map 3. Mound and houses at the Brackett site. 
outside posts 0.45 foot in diameter situated 0.5 foot apart and 1 foot deep. The four center posts were located 8.6 feet apart in a square arrangement, 1.5 feet in diameter and 3 feet deep. No trace of fireplace was found. There was a clay pedestal found directly in front of the entrance, in the house. The feature had been nicked by a plow. There were no burials or restorable pottery found with the house. A number of fragments of points and sherds were found in the test.

There are interesting features in the house types that are worthy of note. The entrances were rows of post moulds in two of the four center-post square houses. In the rectangular two center-post house, the

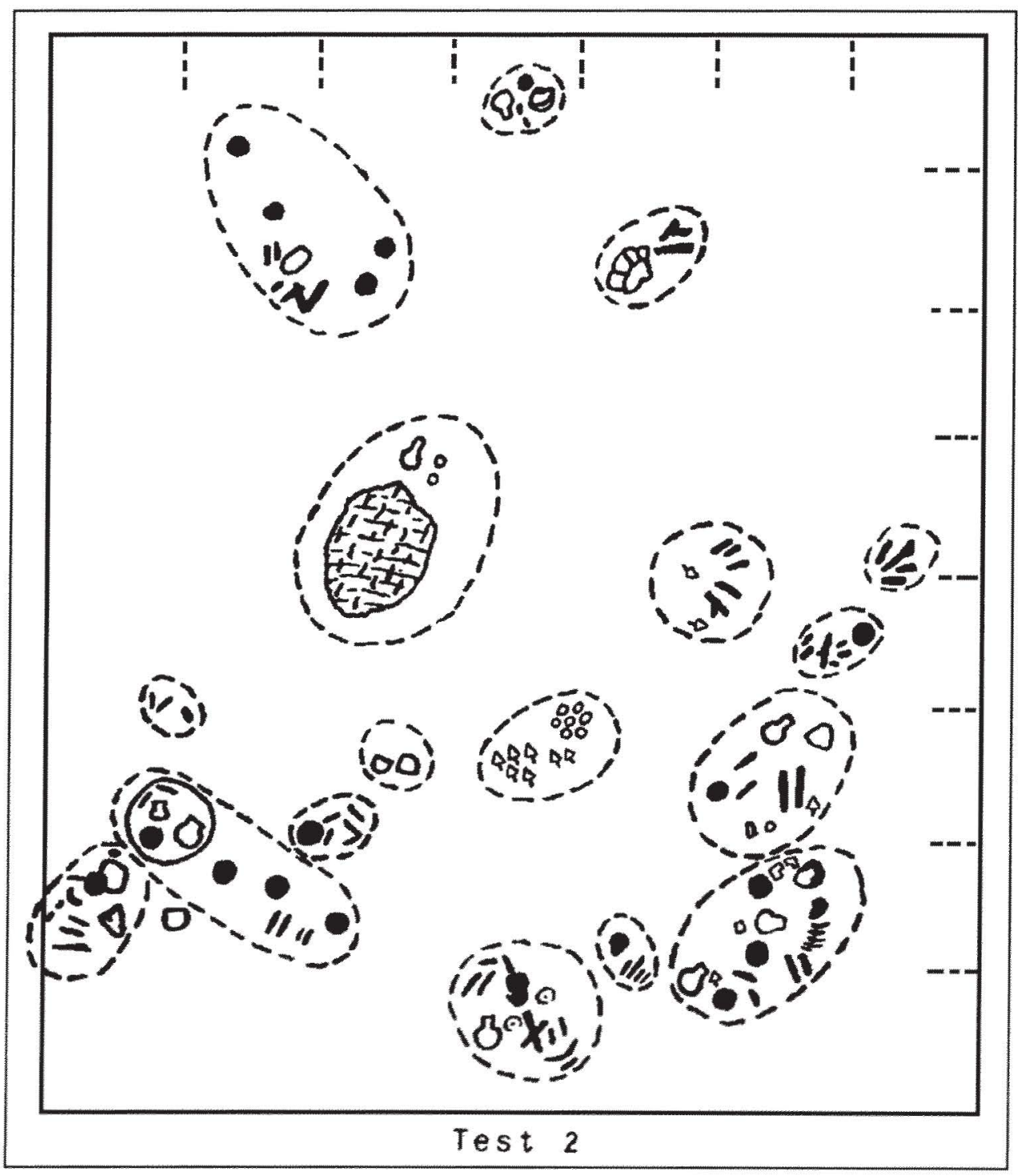

Map 4. Burials at the Brackett site. 
entrance was parallel trenches. Two of the four center-post square houses had parallel trench entrances to the East. The rectangular four center-post house had no entrance that could be located, as the house was shallow and had eroded on the East. One of the four center-post square houses had a trench entrance with post moulds in the trenches. The theory has been suggested that the two center-post rectangular house with trench entrance is a later house. The house types show a gradual transitional stage from the four center-post square with post entrance, to rectangular two center-post, with trench entrance. If this is the case, the transitional stage will be evident in the ceramics and flint work. More study of the other traits is necessary to substantiate this theory.

There were 15 group burials in the village, containing 25 individuals. The average burial was a primary semi-flexed type with grave material. The area in which the burials were found was highly mixed with charcoal and fragmentary material. The burials were all in Test No. 2 , an area of not over 40 feet in diameter (Map 4). All were shallow burials of from 0.5 to 1.5 feet in depth. There was one burial superimposed on another. The burial area was flat, but this could be due to erosion and cultivation, and may have been a small burial mound. The grave material consisted of stone copper-covered ear spools, points, blades, pottery pipes and pottery vessels. The vessel types were water bottles, ollas, curved and carinated bowls. The design elements were incised lines and punctates. The punctates were fingernail imprints, semi-conical and triangular. Secondary features were lip tabs and broad strap handles. The motifs were incised concentric circles, chevrons, scroll, vertical and horizontal lines, and punctate-filled areas. The bases were flat disc shaped, either sharp angle or stilt. There were a few sherds from a square bottomed vessel, and the rims were vertical or flaring. The water bottles were globular in shape, with long tapering necks. Decoration was either on the

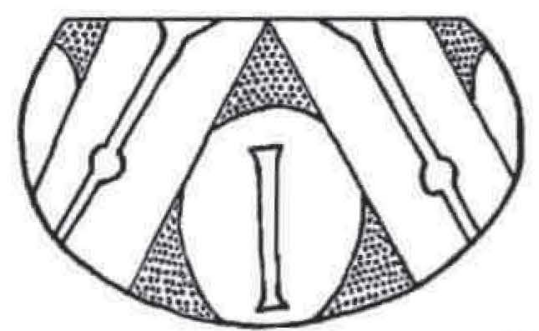

Plate 1: The decorations of deeply incised lines on this bowl found in lext Ho. 2 produce an intaglio effect. The small curved bowl is tempered with sherd and bone and is of black ware.

Type: French Fork Incised (Coles Cr.)

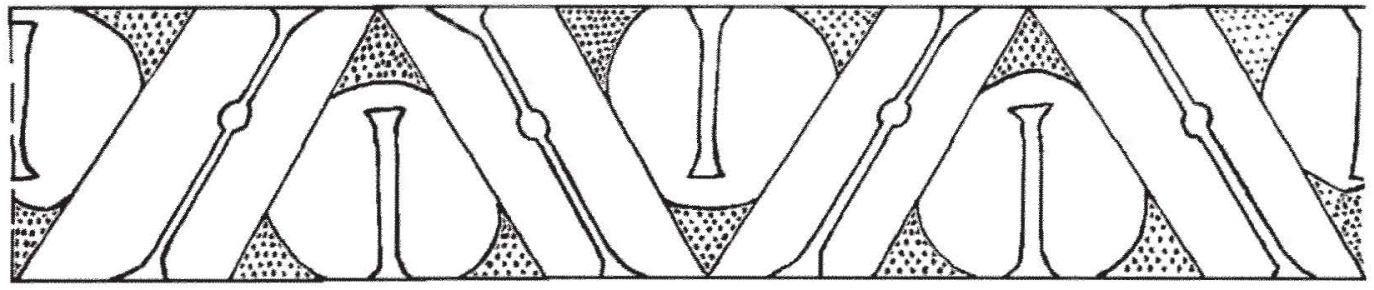




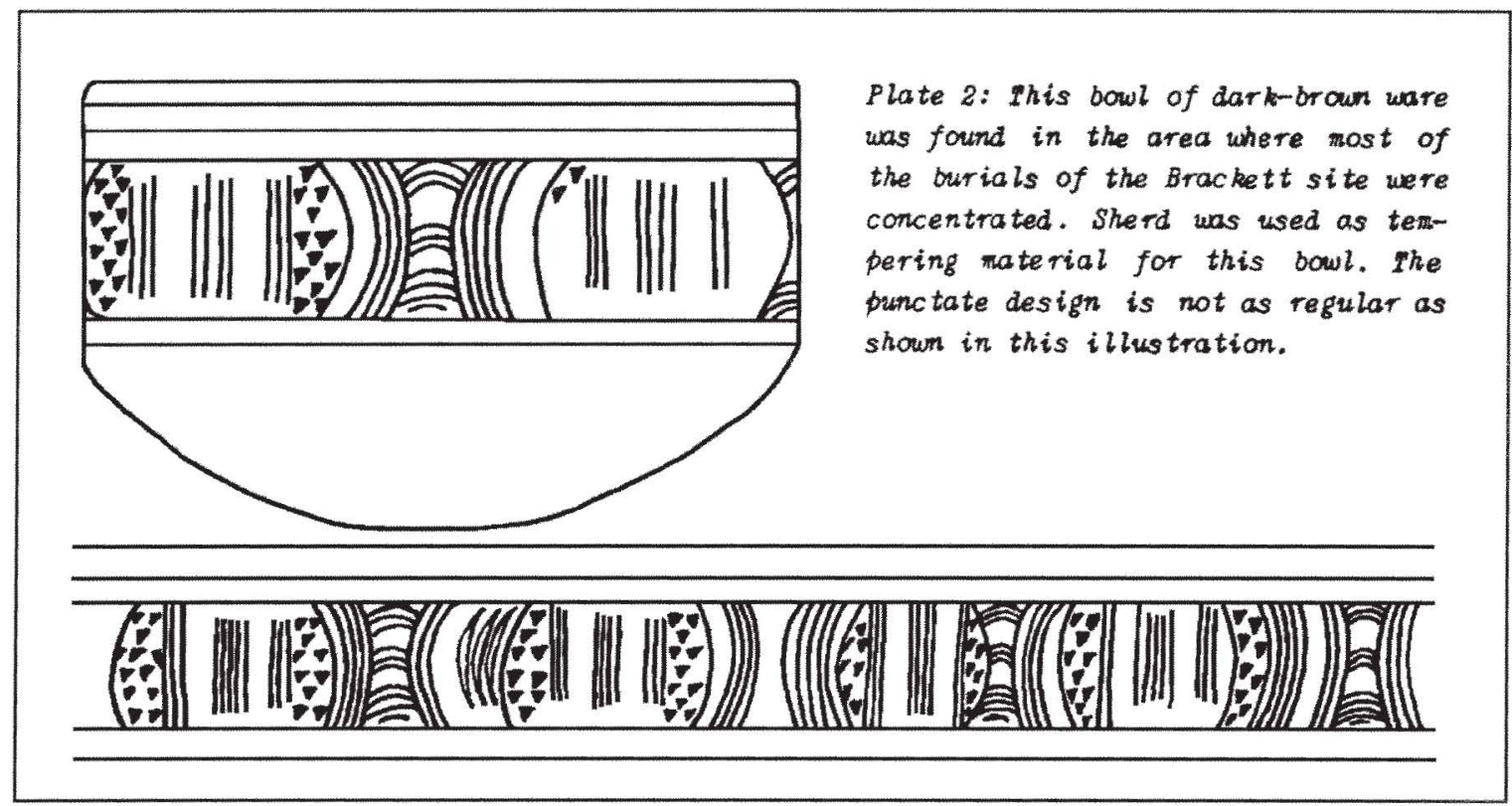

shoulder or the body; a few had horizontal incised lines at the top of the neck. Temper was predominately sherd. A complete count was not made on fragmentary vessels. Drawings of vessels used to illustrate this paper are from Test No. 1, where the burials were found. Plate 1 shows a small black curved bowl with sherd and bone temper. This bowl was labeled "A"-3-1. The design is spread out to show the band of triangles with the deep incised line with intaglio effect. The vertical lined bowl shown in Plate 2 was found in the same test. The temper is sherd and the ware light brown. The punctates were smaller and not as regular as shown in the drawing.

The olla-like piece of pottery shown in Plate 3 was found in Test No. 2. The temper is sherd and the ware dark brown. The elements were incised lines and small irregular punctates. The large carinated bowl, with its large strap handles and lip tabs, illustrated on Plate 3, is of red ware. It has a sherd and bone temper. The design is incised.

Burial No. 1: This burial contained one adult in poor state of preservation. The body was buried in a partly flexed position on the left side. There were two large slabs of fossiliferous limestone, one under the skull and one at the center of the burial. Grave material: Three sherds (brown ware, sherd temper), river mussel and two limestone slabs.

Burial No. 5: Due to the fact that the bones in this primary burial were in a bad state of decay, the orientation was impossible. The bone material found was the skull of an adult. There were two ear spools located several feet north of the skull. The ear spools may or may not have been with the burial. Grave material: Two copper-covered stone ear spools, with a design of double lines forming a cross. 


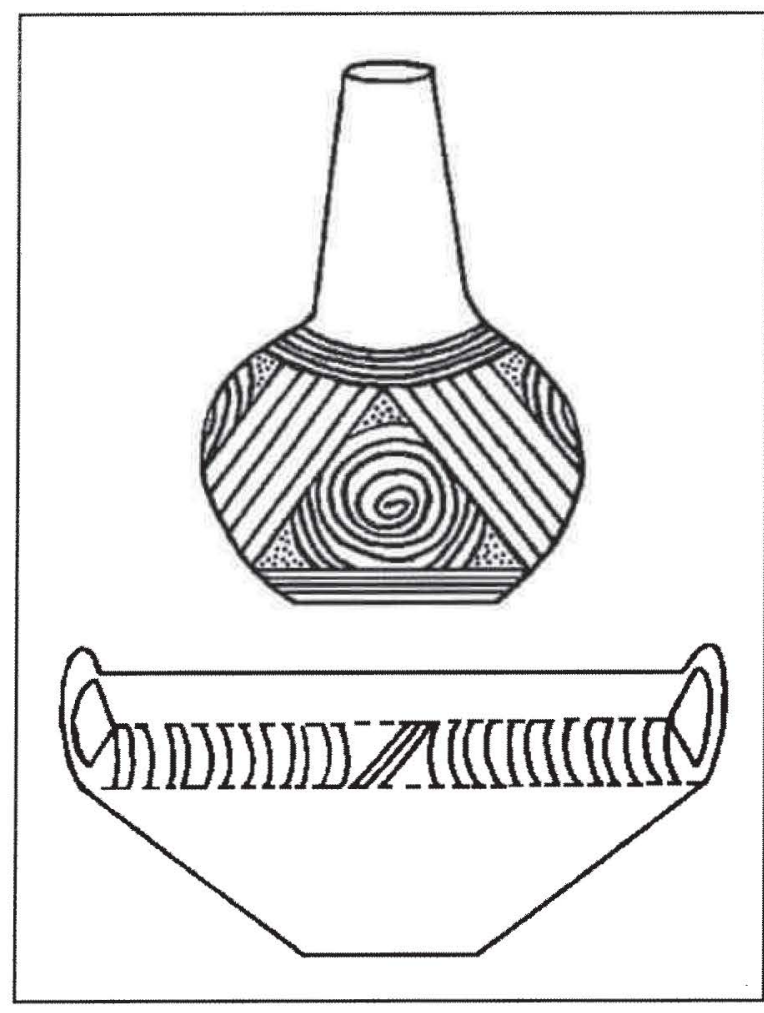

Plate 3. Pottery from Test No. 2.

Burial No. 6: The skull and fragmentary long bones of this burial were in such a state of decay that exact orientation and burial type are unknown. It may be a single partly flexed primary burial. The skull of this burial was only 0.5 foot below the skull of Burial No. 5. Grave material: One plain undecorated, globular water bottle, with brown ware, fine sherd temper and flat base; a pair of stone ear spools with traces of copper covering. The decorations on the spools consist of triple lines forming a cross. Both spools are drilled and the back have been roughly squared.

Certain independent artifacts that deserve special attention were found in Test No. 2 .
These specimens appeared to have been grave material, but due to the soil action and natural decay, no bone material was found with them. These have been an "A" number and notes taken as if they were a burial, as they were, no doubt, grave material.

" $A$ "- 1 : This artifact was a restorable olla with a flat disc base and constricting rim with a small mouth. The ware was black to brown, the temper fine sherd. Design is incised scroll with vertical and horizontal lines.

" $A$ "-2: This was a group of artifacts. There was no bone material, but a slight depression as if there had been a pit burial. There were 20 small SB61 type points and four red-slipped sherds of a water bottle, which were sherd tempered.

" $A$ "-3: One fire-blackened human tooth was found, but there was the lack of direct evidence to connect the tooth with other material, which precluded its chances of being a burial. There was a large mass of wattle in with the specimens, which consisted of two galena balls, incised bowl (Plate 1) and a small black curved bowl.

\section{BRACKETT MOUND:}

The mound was conical in shape and rose seven feet above the surrounding ground. The diameter was approximately 100 feet. Except for a few feeble attempts to find the inevitable "pot of gold", the mound had not been "pot-holed". Because of the efforts of the land owner to plow down the mound, the diameter was rather vague. A large grid was placed over the 
mound, so by a thorough excavation of surrounding soil features associated with the mound might be found. A good house mixture at the west edge of the grid was found as the rows were excavated. Trenching through the area from two directions gave a cross effect and the boundaries of the house, and complete excavation gave the post mould outline of a four center-post square house with entrance to the east. This house and another lying a few feet west were mentioned earlier as part of the village site. The proximity of the house and mound gave the house a mound location as it was within the mound grid, but the mound was in no way superimposed upon the house.

The mound proper began at Row 6 . It was a dark soil heavily impregnated with charcoal, ash and village site debris. This rose from the sub-soil and at Row 9 a layer of ash was found beneath. At row 11 the ash had developed into a definite shape. Starting at the sub-soil it rose gradually for 10 feet, then within the next five feet rose abruptly to a height of four feet above the sub-soil base. The bottom of the ash layer was flat, while the top took the curvature of the mound. The top soil below the ash was a pedestal or platform 30 feet long. On the other side the ash dropped abruptly for five feet, then sloped gradually for the next 15 feet. Charcoal chips, points and sherds were scattered through the top stratum, the ash layer and the soil below to the base. It was as if a low, flat-topped mound was built and then covered with a secondary conical mound. All were constructed of top soil well mixed with sherd, bone and flint fragments. The primary mound is being carefully checked to located post moulds, and if these can be found, then the mound can be called a habitational mound. Twenty feet have been excavated and no post moulds have been located to date. There is a great similarity between this mound and the large mound excavated on the Hughes farm at Muskogee, Okla. The Hughes mound was a flat-topped primary mound with a secondary mound placed over it, and the only material it contained was fragmentary and was inclusive with the top soil when the mound was constructed. Further excavation of the Brackett mound will give a complete picture of the structure and included material.

Fragmentary material from the mound has included a section of a stone "T" shaped pipe. From the sherds so far found, sherd temper predominates. Grit and shell are also found, but do not represent over 30 per cent of the sherds. The ware ranges from light brown to black. One section of a square flat-bottom olla with finger nail prints on the body also was found. Decorated sherds were very scarce due to the fact that the mound was constructed from top soil filled with village debris. The decorated vessels were used more as grave material than for utilitarian purposes.

\section{BLUFF SHELTER:}

As work progressed on the Brackett site, survey work was being done along the Illinois and Barren Fork Rivers and their tributaries. There were several bluffs found, but the shelters had no deposit 
under the overhang. There was one shelter, however, on State Highway 10 three miles north of Tahlequah known locally as "Lovers Leap". The site is owned by Mrs. Kate Smullens and permission was freely granted the University of Oklahoma to excavate. The symbol for this site is Ck. Sm. 1 (Cherokee County), Smullens I [Ed. note: This is 34CK441). The shelter lies to the southeast and has a 30 foot overhang. The complete extent of the shelter is not yet known, but a grid 90 feet long and 40 feet wide has been placed over the shelter. The soil under the shelter of the bluff is very dry and dusty and a test pit could go no deeper than four feet because after that depth cave-ins were inevitable. At the edge of the shelter the soil is moist and more rocks are mixed with the soil. The grid, that was laid out over the shelter, has five foot intersectional intervals. Due to the declination of the alleys from the north the grid was laid out in relation to the wall of the bluff. The system of profiles that is used in the mound excavation must be modified. Row No. 1 will be excavated to a level of three feet and then the next row brought down to that level. Next, Row No. 1 will be lowered three more feet and Row No. 3 will be lowered to the depth of Row No. 2. The excavation will resemble stair steps with the first row being always the lower. The material will be located vertically in six inch levels. As stratigraphy cannot be located from a profile, an artificial system of strata must be adopted until statistical work can locate the levels of occupancy. There is a top layer of loose rock and Caucasion (sic.) picnic debris that must be removed before the layers are begun. This top, or surface, varies from six inches to a depth of 1.5 feet at the edge. The mixture of soil in the shelter contains charcoal, ash, fragments of animal bones, bone tools, sherds and flint artifacts. The animal bones are deer, terrapin, rodents, and a number of river mussel shells. The bone tools were split bone awls, ground to a sharp point. Sherds were light brown to dark brown ware, grit temper, and a few of the sherds were cord roughened. The grit temper was of two types, fine quartz pebbles and crushed limestone. Several of the sherds were from a flat disc shaped base, wide mouthed bowl. The points were all broad stemmed. The SBz type was most common, with SAa next. Many of the points had a rounded or "blunt" point. The worked flint included large core knives, double bladed chipped axes, scrapers, and small flake knives.

\section{CONCLUSIONS:}

The Bluff Shelter on the Smullens' property is little better than in a testing process. Row No. 1 is at a depth of only four feet and Row No. 2 is now being taken down to form the first step. The depth of the deposit is not know, neither is the extent. From this very incomplete picture all conclusions must wait for a more complete excavation.

The Brackett site forms a better basis of comparison. The village site shows a marked similarity to several sites excavated in LeFlore County, Okla. The House Type No. 3, as mentioned by Kenneth G. Orr in The Oklahoma Prehistorian, Vol. II, No. 2 , is very similar to the Brackett four center-post square 
house with a trench entrance. This Type No. 3 has sherd and bone temper, with brown ware. The Brackett site has the same. The rectangular two center-post house with trench entrance was found in close proximity to house Type No. 3 in LeFlore County. The rectangular two center-post house found at the Brackett site had the trench entrance. This all seems to tie in rather closely for casual compari- son. The pottery designs are also similar. The designs shown in Plates 1,2 and 3 are typical of the Brackett site and Spiro main mound pottery. The complete statistical analysis has yet to be made, but unless there are factors that have not been considered which alter the picture, the Brackett site can be located in the Lower Mississippi Phase, Spiro Aspect, with the Focus yet to be determined.

$E d$. note: I have reproduced the graphics in the same orientation that they were given in the original publication. It is obvious, upon reading the descriptions of the structures, that the tops of the maps are not north. 


\section{Some Additional References for the Brackett Site}

Bareis, Charles John

1955 The Brackett Site, Ck-43, of Cherokee County, Oklahoma. Oklahoma Anthropological Society Bulletin 3:1-53.

Bell, Robert E.

1973 Some Comments Upon Chipped Double-Bitted Axes. Oklahoma Anthropological Society Newsletter 21(1):3-9.

1984 Arkansas Valley Caddoan: The Harlan Phase. In: Bell, Robert E. (editor), Prehistory of Oklahoma, pp. 221-240. Academic Press, Inc., New York.

Brown, James A., Robert E. Bell, and Don G. Wyckoff

1978 Caddoan Settlement Patterns in the Arkansas River Drainage. In: Smith, Bruce (editor), Mississippian Settlement Patterns, pp. 169-200. Academic Press, New York.

Klinger, Timothy C., and Robert F. Cande

1986 Cultural Resources Evaluation at Tenkiller Ferry Lake, Cherokee and Sequoyah Counties, Oklahoma. Report 86-9, Historic Preservation Associates, Fayetteville.

Neal, Larry

1974 A Resurvey of the Prehistoric Resources of Tenkiller Ferry Lake. General Survey Report 13, Oklahoma River Basin Survey, University of Oklahoma Research Administration.

Rogers, Daniel

1978 Federally Sponsored Archaeological Work in Oklahoma Before World War II. Unpublished manuscript on file at the Oklahoma Archeological Survey.

Wyckoff, Don G.

1980 Caddoan Adaptive Strategies in the Arkansas Basin, Eastern Oklahoma. Unpublished Ph.D. dissertation, Department of Anthropology, Washington State University, Pullman. 